\title{
Landscape Game: A model to understand the dynamics of land competition, policy measures and sustainability of a landscape
}

\author{
Herry Purnomo ${ }^{1,2)}$ and Rika Harini Irawati ${ }^{1)}$ \\ 1) Center for International Forestry Research (CIFOR), Bogor Barat 16115 \\ Indonesia.email:h.purnomo@cgiar.org \\ ${ }^{2)}$ Faculty of Forestry, Bogor Agricultural University
}

\begin{abstract}
The landscape is a complex place where ecosystems and humans interact. Various actors have interests in landscapes and struggle for their livelihoods and benefits. The landscape itself is alive, growing and giving back either positively or negatively. No one can exactly project what can happen to a landscape in the future with these complex actor interactions. A non-computerized tool called "Landscape Game" was developed based on game theory to help understand the dynamics of land competition, policy measures and sustainability of a landscape. The game combines concepts of Monopoly, SimCity, American Farmer, Snakes and Ladder, cellular automata, game theory and genetic algorithms. The Landscape Game operates on a landscape scale, covering a mosaic of various land cover and land use patches including forest that work as an ecosystem. Through this game, stakeholders can experiment with the likely impacts of human actions in a landscape where competing land uses and policy dynamics interact. Policy makers can learn how to maintain and improve the sustainability and productivity of a landscape by using various policy instruments, e.g., rules, taxes, land use, incentives and disincentives. This game introduces a variety of concepts such as landscape conservation, development, environmental services including REDD+ (Reducing Emissions from Deforestation and Forest Degradation), investment alternatives, trade among players, and competition and collaboration. The game challenges rational players to maximize their revenues, while at the same time taking care of the ecological and social conditions. This paper describes how the Landscape Game was developed and played with various stakeholders as well as lessons learnt. We expected the game learning process to change players' mental model previously conveyed by the players.
\end{abstract}

Keywords: game, landscape, actors, policy, learning 


\section{INTRODUCTION}

Managing natural resources means managing an ecosystem with various stakeholders who have interests in the ecosystem. In reality, the stakeholders act and behave with conflicting interests and respond in like manner to each other. Synergy is a good, but often trade-offs among stakeholders occur. Resource users often behave individually to maximize their interests and may change their strategy and action to respond to other users. Other stakeholders i.e., policy makers need to find policy measures to sustain the ecosystem. After all, life is a game.

A game is an action that triggers a reaction, which then triggers further action and more reaction. A game is characterized as: a) a free activity; b) having imaginative components; c) bounded by space and time; d) can trigger group discussion; and, e) mimic normal behavior. Behind a game is a body of knowledge called 'game theory', which spells out how rational individuals make a decision when they are interdependent. In game theory, individualism, rationality and interdependency are some of the basic theoretical constructs that predicate the behavior and disposition of the players (Romp 1997).

Meinzen-Dick et al. (2004) provided an overview of studies that present applications of qualitative, quantitative, experimental, and action research methods including experimental games for studying collective action. Game is an innovative tool that can be used to develop a coordinated strategy among different actors. Such strategies may also lead to the development of new institutions and revitalize existing ones. The game's realism may take one of several forms: (a) Explicit reality, where game presents the actors' real situation and their resources; (b) Implicit reality, where game represents a simplified version of actors and their resources; and, (c) Virtual world, where game is based on an issue that is not necessarily related to a specific actor or resource.

This paper describes the development of the landscape game, which takes on a realism of the virtual world. The game was developed based on the issues of competing use of land, maximize benefits for each set of actors and sustainability of forest landscape. As defined as a normal game, the developed game elements comprises players, set of possible strategies in forest landscape and pay offs. This is a simple and non-computerized game and is expected to be played by people from different backgrounds ranging from local communities, policy makers, students and academicians. The game aims at providing lessons for its players and observers and shows what can occur to the landscape and players' income when the players apply various strategies after a specific time period. It includes how Nash Equilibrium, in which all players apply optimal strategy, is approached. These lessons are expected to contribute to the development of appropriate strategies and institutions of multi-stakeholders for forest landscape management.

\section{CONTEXT: LANDSCAPE MANAGEMENT AND THE GAME THEORY}

The game takes place at the landscape level. Landscape is a mosaic of different land cover and land use patches, which work as an ecosystem. The overall goal of landscape management is sustainability of ecology, social and economic functions. Discussions on landscape management commonly includes multiple scales, ecological integrity, monitoring, adaptive management, cooperation, humans as an ecosystem components, and human values as dominant in goal setting. The complexity of the landscape makes active adaptive management highly recommended. This game is expected to provide a model for stakeholders to learn about the likely impacts of human being strategies, implemented in a landscape mosaic where competing land use exists. This learning process can change players' mental model previously conveyed by the players (Cárdenasa and Ostrom, 2004).

As indicated by Romp (1997), a normal game shall have players, available strategy for each players and pay offs. The landscape game combines concepts of Monopoly, SimCity, American Farmer and simplified classifiers genetic algorithm as explained by Purnomo and Guizol (2006). The game takes the power of investing and trading of property in Monopoly, cellular automata in SimCity, agricultural investment of American Farmer and rules dynamics of classifiers genetic algorithm.

\section{GAME DEVELOPMENT AND PLAYING METHOD}

The landscape game challenges its rational players to maximize their income, while at the same time they shall take care of the ecological and social conditions, which are indicated by various indicators. The ecological indicators include landscape diversity and ecosystem services such as water and carbon. The social indicators include the gap between the 'haves' and the 'have nots' after the game is over. The player who is able to play 'friendly' in terms of these indicators will be rewarded at the end of the game if the overall landscape has improved 


\subsection{Players}

The game is played ideally by six persons, who consist of four players, one banker and one ecosocial judge or government. The game needs at least three persons, two players and one banker, who can also act as the government. The players actually compete in the game. Their moves are controlled by two or three dice. The players think, invest, get investment returns, experience events such as flood and fire, negotiate to buy and sell property etc. They are challenged to maximize their prosperity including assets. The winner of the game is the richest player.

The banker distributes the money at the beginning to all players. The banker takes care of all transactions including investments, paying investment returns, giving loans, receiving property hypothec etc. The game challenges the banker not to loose their money. Though, it is not the main aim of the game. When the banker gives a loan to the players, they identify appropriate interest rates.

The government or eco-social judge judges the overall landscape during and when the game is over. The assessment is based on the following ecological indicators: (a) existence of natural forests; (b) water sources are maintained; (c) investment for carbon sequestration; and social indicators: (a) investment in agroforestry; (b) gap between rich and poor players. If the landscape is getting better in terms of ecological and social indicators then the government will give a reward to the best player(s).

The government may distribute rewards to several players that play the game eco-social friendly. In order to make the judgment transparent, the indicators for assessment must be announced at the beginning. The role of eco-social judgment is commonly played by a government. The judge, in order to maintain or improve sustainability in terms of economy, ecology and social aspects, can modify the game rules after the game is halfway through. For instance, if the game is played for one hour, the judge can modify the rules after 30 minutes. The rule modification is limited to give incentive or disincentive for certain investments and to forbid certain investments.

\subsection{Spatial Setting and Payoffs}

To draw the initial landscape we thought of three types of areas, i.e., forest core, forest edge and mosaic-lands as proposed by Chomitz (2007). The "Landscape game" provides spatial concepts which include land competition, cellular automata, forest cover, community settlements, rivers and roads (Figure 1). You can think of a cell as representing 1,000 ha, so that altogether the board represents 100,000 ha of land. Land competition means that land is limited. If a player already uses the cell then the others cannot use it anymore. They have to buy the land. Cellular automata means that the neighboring land plots can have a direct or indirect effect on land plots. For example, you can buy as an investment if you are located in or adjacent to that investment. Each plot has a different characteristic (core, edge, mosaic-land). A road divides the landscape. Investing in plots close to the road tends to be cheaper than investing in plots far from the road. Social costs emerge if the investment is adjacent to community settlements. A river flows across the landscape.

The landscape game, however, also contains potential coal mining, HCVF (high conservation value forest) areas and local community settlements. Some cells (plots) are dedicated for game playing. They are cells labeled with sustainability funds, fire and landslide. Cells for 'Sustainability Fund' are places where you take a card and see what is written on it. You may receive all the money collected from 'fire' and 'landslide' cost payments from the other players.

The investment types will depend on what area types a player is located. Investment time is a time period to obtain investment returns. One rotation means a period when the user comes back to the cell where $\mathrm{s} /$ he invested previously. For instance, if s/he invests in cell no 15 , she needs to move from 15 to 100 and from 1 to 15 in order to complete one rotation.

\subsection{Game Playing Method}

The game has been played many times. For this paper we illustrated two games one played in Bogor and the other in Bangkok. The two games were played by four students from the Faculty of Forestry, Bogor Agricultural University. And the other one was played by RECOFT-University of Wageningen training on Governance. The participants came from many different institutions and various backgrounds.

Initially, players are randomly located by tossing dice onto the landscape, which is divided into randomly scattered patches numbered from 1 to 100. Players begin from the patches in which their die lands. Each move is driven by the cumulative points of three dice bearing the values 1 to 6 . If a player tosses three 
sixes, producing 18 steps, then the player deserves to move once more. Players move towards patch no. 100, and then restart from patch no. 1, until the agreed time period of play is completed. The game manual can be seen at http://www.cifor.cgiar.org/LPF/landscapegame/

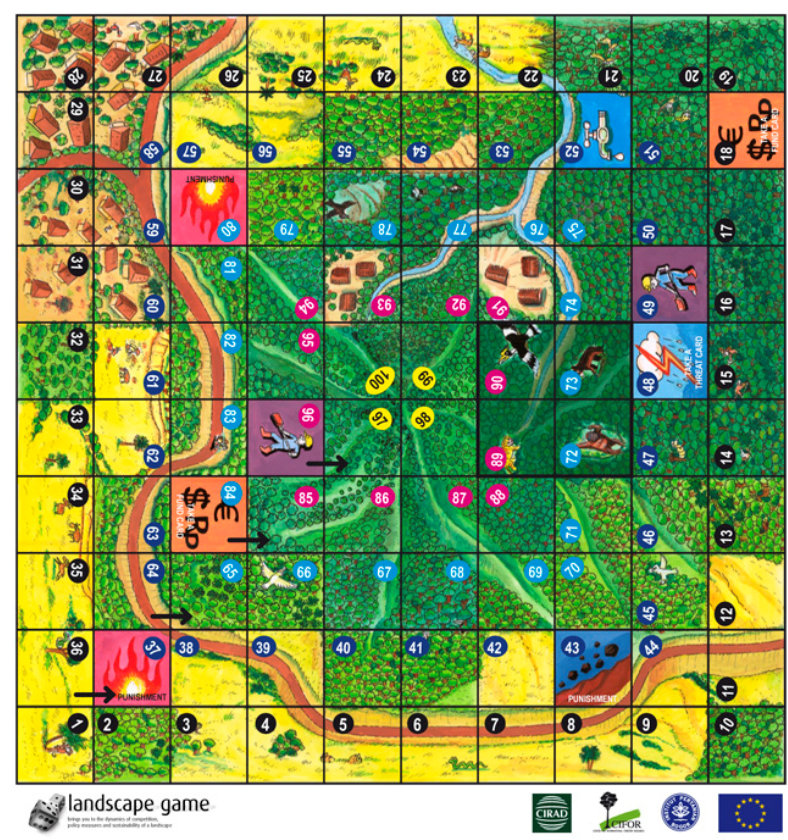

Figure 1. Landscape game

\section{RESULTS}

The first game was took place at CIFOR Campus. The players were students from Faculty of Forestry, Bogor Agricultural University. There were four players in each game, plus one person as an observer and advisor to the 'government'. In the first game, the author acted as the government, bank and observer. The result of the first game is shown in Table 1.

In the first game, the government did not set any rules at the beginning of the game since the landscape was still in a good condition. But as agreed by all players, along the game there were some rules that needed to be followed. There were also incentives e.g., if a player had invested in the water (there was only one water cell in this game) every time another player invested in anything at all, they were required to pay $5 \mathrm{p}$ to the owner of the water cell. The players followed the rules set by the game manual. Each play must throw the dice and move their counters the total number obtained. Each player must then complete the circuit returning to that cell in order to start another circuit. As a result, the game was won by Player $\mathrm{C}$ with 240 points, followed by Player A with 139 points and Player B with 129 points.

Table 1. The result of the first game played by students

\begin{tabular}{|l|l|l|l|l|l|l|}
\hline \multirow{2}{*}{$\begin{array}{l}\text { Investments, cash and } \\
\text { loans }\end{array}$} & \multicolumn{2}{|l}{ Player A } & \multicolumn{2}{l}{ Player B } & \multicolumn{2}{l|}{ Player C } \\
\cline { 2 - 7 } & Landscape & Value & Landscape & Value & Landscape & Value \\
\hline Assets & Teak & 50 & Ecotourism (2) & 14 & Carbon (2) & 10 \\
\hline & Oil palm & 16 & Logging (2) & 14 & Bio fuel & 5 \\
\hline & Carbon (2) & 10 & Albazia & 25 & Acacia & 17 \\
\hline & Logging & 7 & Oil palm & 16 & Teak & 50 \\
\hline & Ecotourism & 7 & & & Water & 40 \\
\hline & Acacia & 17 & & & & \\
\hline
\end{tabular}


Purnomo and Irawati, Landscape Game: A model to understand the dynamics of land competition...

\begin{tabular}{|l|l|l|l|l|l|l|}
\hline Cash & & 32 & & 50 & & 118 \\
\hline Total & & 139 & & 129 & & $\mathbf{2 4 0}$ \\
\hline
\end{tabular}

The second game used three dice and all players started from cell number 1 . This rule was suggested by the players because in the first game they forgot where they had to finish (i.e., the patch they started on) in order to get investment returns. So the players agreed to finish the game when all players had reached cell ' 100 '. The result is shown in Table 2. The second game was won by Player C with 182 points, followed by Player B with 129 and Player A with 121.

Table 2. The results of the second game played by students

\begin{tabular}{|c|c|c|c|c|c|c|}
\hline \multirow{2}{*}{$\begin{array}{l}\text { Investments, cash } \\
\text { and loans }\end{array}$} & \multicolumn{2}{|l|}{ Player A } & \multicolumn{2}{|l|}{ Player B } & \multicolumn{2}{|l|}{ Player C } \\
\hline & Landscape & Value & Landscape & & Landscape & Value \\
\hline Assets & Water & 45 & Acacia & 17 & $\begin{array}{l}\text { Ecotourism } \\
\text { non HCVF (3) }\end{array}$ & 23 \\
\hline & Carbon & 11 & Ecotourism & 7 & Carbon (3) & 21 \\
\hline & $\begin{array}{l}\text { Ecotourism non } \\
\operatorname{HCVF}(2)\end{array}$ & 18 & Carbon & 5 & Oil palm & 75 \\
\hline & Logging & 57 & Teak & 50 & Logging & 57 \\
\hline & Ecotourism HCVF & 18. & & & & \\
\hline Cash & & 22 & & 50 & & 6 \\
\hline Loans & & $\mathbf{5 0}$ & & 0 & & 0 \\
\hline Total & & 121 & & 129 & & 182 \\
\hline
\end{tabular}

The third game was played in Bangkok at the RECOFTC-University of Wageningen training on Governance. The participants came from various background and expertise. They also came from various countries (Indonesia, Guatemala, Costarica, Colombia, Cambodia, Bangladesh, Kenya, Burkina Faso, Mongolia, Namibia and Nepal). Since there were many participants in the training, the game was set for 4 (four) players with 1 person acting as the government. But other participants were also involved in the game and became the advisors and team for the players. The result of the third game is shown in Table 3 . The game was won by Player A with 198, followed by B, D and C.

Table 3. The result of the third game for RECOFT-University of Wageningen training on Governance

\begin{tabular}{|l|l|l|l|l|l|l|l|l|}
\hline \multirow{2}{*}{$\begin{array}{l}\text { Investments, } \\
\text { cash and loans }\end{array}$} & \multicolumn{2}{l|}{ Player A } & \multicolumn{2}{l|}{ Player B } & \multicolumn{2}{l|}{ Player C } & \multicolumn{2}{l|}{$\begin{array}{l}\text { Valuer D } \\
\text { e }\end{array}$} \\
\cline { 2 - 9 } & Landscape & Value & Landscape & Value & Landscape & Landscape & Value \\
\hline Assets & Albizia & 7 & Albizia & 25 & Biofuel (2) & 10 & Teak (2) & 100 \\
\hline & Water & 40 & Logging & 14 & Carbon (5) & 25 & $\begin{array}{l}\text { Ecotourism } \\
(4)\end{array}$ & 28 \\
\hline & Ecotourism & 15 & Carbon & 10 & Ecotourism HCVF (2) & 14 & Coal mining & 30 \\
\hline & Carbon & 5 & Bio fuel & 10 & Forest Logging & 7 & & \\
\hline Cash & & & Ecotourism & 21 & & & & 237 \\
\hline
\end{tabular}




\begin{tabular}{|l|l|l|l|l|l|l|l|l|}
\hline Penalty & & 110 & & 110 & & 110 & & 220 \\
\hline Total & & $\mathbf{1 9 8}$ & & 193 & & 75 & & 175 \\
\hline
\end{tabular}

In the first and second game, where the players came from the same background, conflicts existed. They were all competing and applying various strategies to win. The players were thinking only of making profitable investments without disturbing the sustainability of the landscape. Player A invested in teak because it gave high returns after two cycles. He also invested in oil palm, acacia plantations and forest logging because of the high returns after one cycle. In order to maintain the sustainability of the landscape, he invested in ecotourism and carbon. Player B also invested in forest logging and oil palm to get high returns. Similar with player A, Player B invested in ecotourism and carbon to maintain the landscape. But these two players received disincentives from the government, as the 'judge', because they invested in forest logging. They had to pay a penalty on their investment. Player $\mathrm{C}$ become the richest player and received the most cash because of his investment in water. He also invested in teak and acacia plantations to get high returns.

In the second game, Player A invested in water and received $5 \mathrm{p}$ return for every investment made by other players. He applied this strategy because in the first game, the player who possessed the water received returns from the other players. But, he did not win because of a loan from the bank. The rules of the first and second game were similar. We modified the rules half way through the game. The modification included the penalty fee or additional cost for investing near the community, road or other common property and the starting point on cell ' 1 ' for the second game. Sometimes the players negotiated with the bank and government in order to get incentives or to avoid the disincentive given by the judge.

The third game was more interactive and many conflicts occurred. Again in this game, the winner was the player who possessed the 'water' investment. The conflicts happened because sometimes the players felt that the government was unfair. A regulation such as a fee or penalty was sometimes set after one player got the benefit from one investment, so the others who applied the same investment didn't want to obey the new rule. Various backgrounds of the players affected the investments they made. None of them played 'safely'. They were all competing to win the game by making the most valuable investments for the highest returns. But on the other hand they still wanted to keep the sustainability of the landscape and negotiated with the government to avoid punishment.

\section{DISCUSSION}

During the game all players imagined and connected the game's spatial landscape, social actors and rules to reality. Each player had different experiences in reality. Some had more experience in natural forests and the others had more in planted forests, community forests, carbon trading, advocacies or policy work. Although the players' experience, in reality, differed in detail to the game, they thought the game could represent a general landscape in reality. This may not necessarily be a particular real landscape. The pattern of landscape in the game, which follows the idea of Chomitz (2007), could be accepted as a virtual world landscape.

The initial rules, incentives and disincentives in real landscape management varies from place to place. In some places the government still implements timber logging as the main source of income from landscape management. In other places, where the players came from, their governments are shifting to focus on ecosystem services as the main focus of landscape management. Incentives for carbon based management through REDD+ (Reducing Emission from Deforestation and Forest Degradation Plus) for instance is now occurring and incentivizing as well in some places. Incentives are also given to boost the community forestry activities. The governance system in terms of transparency, participation and government effectiveness and corruption levels also vary in reality. The landscape game provides a general system that could happen in landscape management, where the players can execute strategy, scrutinize the response from other players as well as policy makers, and examine the impacts of different strategies on a landscape.

The game is fun due to the uncertainty of the dice and unpredictable responses of the other players. The players enjoy the excitement of rolling the dice on the board that then determines the advantages or disadvantages each player receives. They also enjoy seeing how good a strategy is or isn't. For instance, if a player invests in a teak plantation that needs years to produce timber, but the game finishes before the teak provides a benefit. The game also encourages the players to think of strategies to win, predict other players' strategies and how policy makers develop, implement and change rules. The game encourages policy 
makers to development policies to maintain the landscape sustainability in harmony with its productivity. The policy makers need to encourage people to invest their money in planting in a mosaic landscape, carbon trading, ecotourism etc., to make the landscape productive.

The statement "If we were all better people, the world would be a better place" was mentioned by Levine (n.d.) could be applied to this game. In order to make a better landscape and to make the landscape productive, all players try to be 'better' people. But at the same time, they were also taking risks when investing. Hence, this situation causes conflicts and makes the 'policy maker' a 'bad guy', because the government tries to make the landscape profitable for all players and also productive in terms of investment.

It is very important for policy makers to be fair to all players to make the game run smoothly. The policy maker can implement principles of good governance such as participatory, accountability, transparency and effectiveness to sustain the landscape. During the game the students tended to experiment with all possibilities. They started by playing 'safe', but then tried to play 'extreme' e.g., maximize their profits. While practitioners tended to represent their daily activities in the game. So, if they come from forest concessionaires they tend to invest in timber logging activities, if they are conservationists they tend to invest in ecotourism or carbon trading activities. The players also suggested the game could be improved by putting industries, communities and other stakeholders in the game. They also suggest to involve community (as a player) to set the regulations. But in reality, the community is often not involved in setting regulations.

The fundamental question is whether the landscape game can change the mental model and behaviors of the players. We believe by playing the game the players understand better the concept of landscape management. The following are the impacts of playing the landscape game: (a) more knowledge of winning strategies ; (b) understanding reciprocal strategies of the "opponents"; (c) a sense of integration between development and conservation activities; (d) anticipating new policies as a result of their activities; (d) experiencing developing new policies to sustain the landscape and maintain its productivity. These lessons learnt can then change the players' mental model. This new mental model can then be implemented in the real landscape where the players are facing or will be facing in the future similar situations.

\section{CONCLUSION}

The landscape game is a virtual reality, where players can experience development, conservation and policy implementation in a landscape. The game is fun and can stimulate conceptual thinking of landscape management. Although each landscape and its rules are different from place to place, the landscape game is able to represent the common landscape and its management. The players can understand how opponents will respond to their strategies, impact their strategies as well as policy responses to their strategies. The players can learn lessons that can be implemented in a real landscape.

\section{REFERENCES}

Atrana S, Medinc D, Rosse NO. 2005. The Cultural Mind: Environmental Decision Making and Cultural Modeling Within and Across Populations. Psychological Review. 112(4):744-776

Cárdenasa JC, Ostrom E. 2004. What do people bring into the game? experiments in the field about cooperation in the commons. Agricultural Systems. 82(3): 307-326

Chomitz KM. 2007. At Loggerheads? Agricultural expansion, poverty reduction and environment in the tropical forests. The World Bank, Washington DC. 284pp.

Levine, D.K. no date. Economic and Game Theory What is Game Theory?. Department of Economics. UCLA.

Meinzen-Dick R, DiGregorio M, McCarthy N. 2004. Methods for studying collective action in rural development. Agricultural Systems. 82(3): 197-214

Ostrom E, Gardner R, Walker J. (1994) Rules, games and common-pool resources. The University of Michigan Press.

Purnomo H, Guizol P. 2006. Simulating Forest Plantation Co-management with Multi-Agent-System. Mathematical and Computer Modeling 44(2006): 535-552

Romp G. 1997. Game Theory: Introduction and Applications. Oxford University Press, Oxford. 284pp. 